\title{
DEGRADATION OF TOTAL PETROLEUM HYDROCARBON AND BTEX COMPOUNDS IN PRODUCED WATER
}

\author{
INTERIM REPORT
}

November 16, 2001 - January 10, 2002

Date Published: April 1, 2002

Approved by:
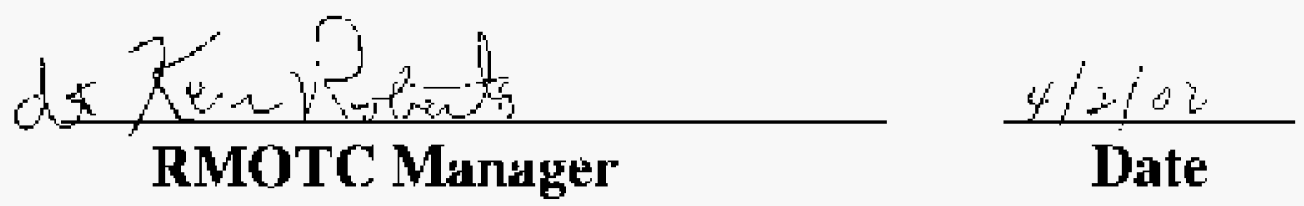

L.M. Jackson

\section{PREPARED FOR TIIE UNITED STATES DEPARTMENT OF ENERGY/ROCKY MOUNTAIN OII.FIFID TESTING CENTER}

Work Performed Under Rocky Mountain Oilfield

Testing Center (RMOTC) CRADA No. 2001-010 


\section{Disclaimer}

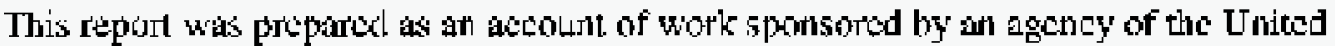
Sratcs Government. Neit]el the Lnited States Government nor any agency thereot, nor any of their employees, make iny warnty, express or implied, nor assumes ang legal liability or responsibility lor the accuracy. completencss, or usefultess of aly jnformation, apparatus, product, or process disclnsed, or represents that its use would nol intinge priwately owned rights. Reference herein to any spevific sommercial britucl, phocess. or service by rade natne, uradematk, manufachurer, or othewise does not flecessarily: constitute or imply its endorsement, Jecommendation, or favoring by the Lited States Goremment or any atrency thereal. The views and opitrions of anthot exprassed herein do nol necessarily slate or follect those of the Unitod Slates Gomernmeth or any agency therenf. 


\begin{abstract}
Abstrutet
Petwleum Ejsironmental Technologies, LLC elltered inlo a Cooperative Research and Development agroetnont with the Rocky Mounlain Oifficld Testing Centes to an in-silu pit treatmont destonstration and produced water thatment demonstration. The purpose of the test

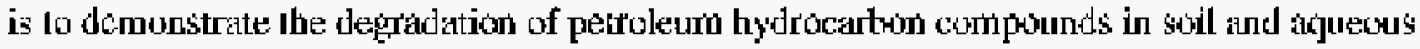

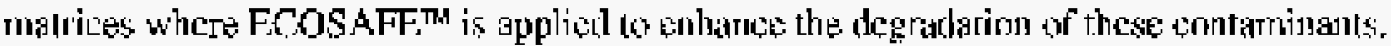

ECOSAFE'M is a mixure of nutrients that blends nathral seguestronts, surlatidals, and ctrulsifying agents. It is $100 \%$ bjodegtadable, is nor harmful 10 marinelaquatic life atsd safely

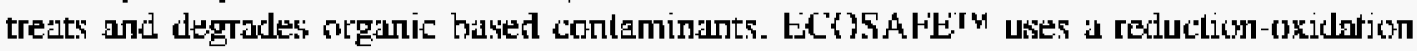
reaction to degrade the tageted organic compound. This reation roduces the target com nound tro yitrales, oxysen, carbon dioxide and water. Another impontant aspect of this technology is the simulantous treatment of the contaminated soil and ground water. The ECOSAFE $1 \mathrm{k}$

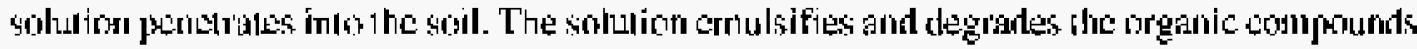
by breaking them up intu suspended particles. These paricles repeal each other thereby

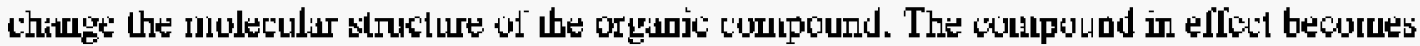
water-soluble. The result is a mix cute of dissolved oxygen, carbon dioxide, and nitrates using the hydrogen of water as calalytic agent.
\end{abstract}




\section{Introduction}

Petroleum Envitntmental Technolngies, LLC., a Flunidian Corporation re]ocitog to Casper, Wyonizg, contricted with the Rock Mountain Oifficld Testing Contor (RMOTC) of Casper, Wyomitag to demonstrate an in-situ application of the non-hazardows product ECOSAFE. ${ }^{\mathrm{T}}$ Aloug side the full-scale field trial, a bench scale produced water expeniment was conducted.

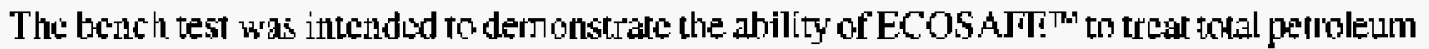
bytrnearbon and $B$ TFX comprunds in porduced water column whjle simultancous]y tredting the soil matrix.

The data presented in this report was collected from Nowember 16, 2001 to January 10, 2002.

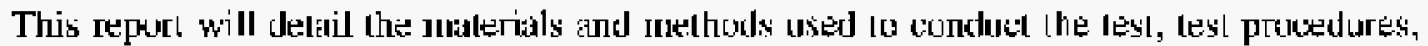
lahoratory results, and conclusions.

\section{Experimental Design}

Two 55-gallon dnims were recycled fron the cheminal storage yand and theand for this test. The drums wete filled with fluid telriered from a ptr localed at the Water Disposal Facility. The fluid was a mixture of water, oil and other unknown waste products. There wias nospecial preparalion of the fluid prior to filling the drams.

The drums were placed side by side on a pallet. Hur each drum, air injecticn tubing was

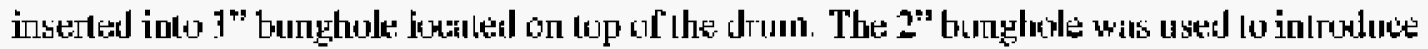
the fluid to the elturn. (See Appendix C).

The lluid was extracted from the Water Disposat Facility pir using a vacuum truck and transportes in the PFT test site. The fluid was discharged from the truck threngh a I ${ }^{m "}$ hose into the 2 " burghole on top of the drusns. There was no filter applied to the end of the hose.

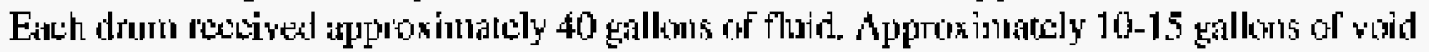
space was left inside each doum to allow for potential orerflow when the air injection cycle began.

Samples of the fluid column inside horth drums was collected and anglyzed to establish a

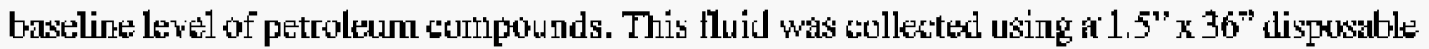
hailer. The rerrievil bapacity of the hailer was approxitrately 1 liter. The haibar was insertert

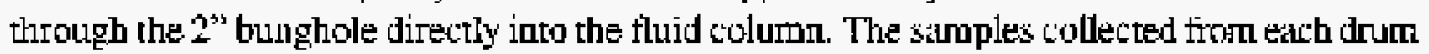

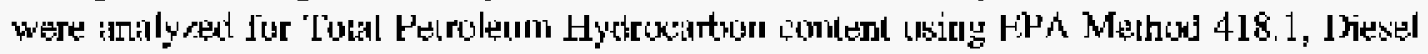
Range Organics using FPA. Method 8015P Madified and Volatile Organic Corpounds Suitz (Benzene, Tolwene, Ethylebena, Xylene) using EPA Method bon $1 \mathrm{H}$.

Next, one gallon of FCOSAFETM solution was added to each drum using a hand purep to dispense the prowlut inta the dum. A 24 inch stainless-steel pjpe was insented vertically into the 1 " bunghole if each duiw. The pipe was purforated at 3 inch spacing along the lenght of the pipe to faciliate even agitation whe lluid. Air was injected ioto cach drum all anerage rate between 90 psi and 120 psi. The air compressor ran 24 hous a day It cycled on when the pressure lell to ou psi and cycled of when the pressure reathed 120 psi. 
On the $55^{\text {d }}$ day of the test. a sectond set of samples was collected from each drum. These

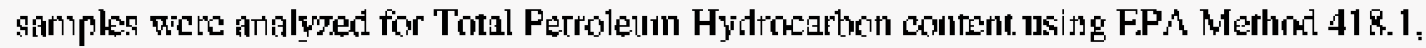
Diesel Range Urgatics using EFA Method BOLSB Modified and BTEX (Benzene, Toluene;

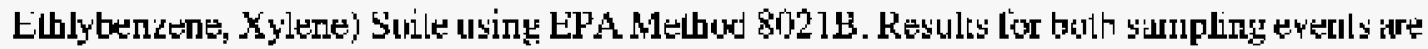
listcd in Table 1. Full laboratory analy sis reports are containod in Appendix A.

\section{Discussion}

The purpose of this bencl test was to demonstrate the ability of ECOSAFE' to degrade

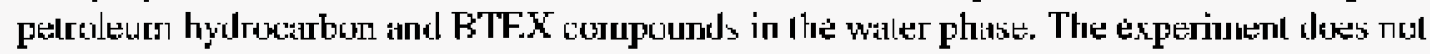
compare a contiol set to a treated or test set. Instead, it provides an example of petrolem hydrocaton and BTEX degradalion in a controlled experiment to be degradation ol those

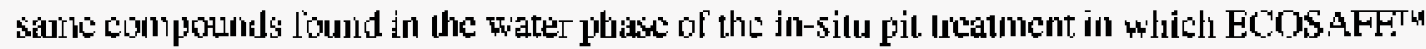
was mixed wilh produced witer and injected into the soil column.

The alalyses parmeters chosen for this test were important to demonstrate and document key functions of this lechnology (1) A general pregenec of pecrolum hydrocarbons should be establislied using a test method widely accepted by most state reguladary agenciess, (2) Test for

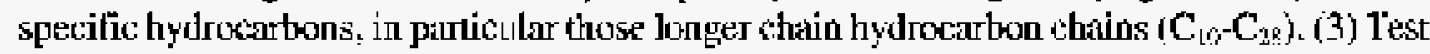
for those compounds that represent a risk to public heath and the enwironment becau Be they are relatively soluble in water and can diffuse mpidly once introduced into an aquifer (volatile organit compoundsi.

EPA Test Melhod 418. I, Total Petroleum Hydrocurbolis is widely used as a general IIeasure of the presence of erde gil or pelroleuml product in waler and soils TPH is tefined as the Teasurable ammant of percoleum-hased hydrocarbon in an environmental media. While TPH provides an owerall concentralion of petroleum hydrocarbons in a media, it is nol a direct

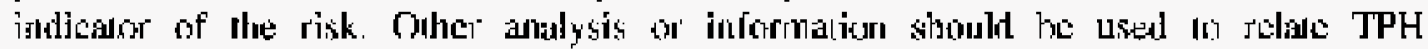
concentrations to risk. Duing this test, ECOSAFE" significantly reduced the measurable amount of pertuleurn hydracarbots in the waler phase, in one case, over a $90 \%$ reduction was

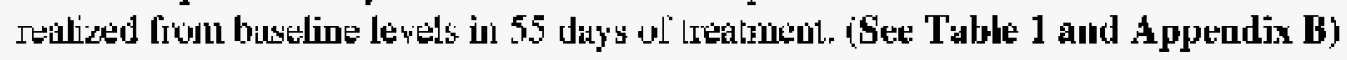

El'A Melhod 8015 Modilied reports the concertration of purgeable and exiractable

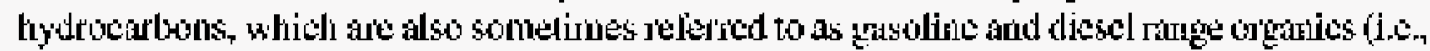
GRO and DRO). Purgenble lydrocarbons are measured by purgo-and-turp gas chronatography (GC) analysis using a lande ionizalion delector (FI). while the extraclatio bydrocarbons ate analyzed by GC following cxtraction with a solwent and subsequenc concentration of the extract by evapmation. While more detailed infornation is generated by

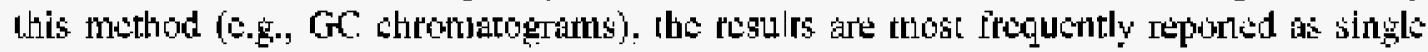
number's for prigealse and extractable ligdrowatbons. For the pulposes of this report. TRO

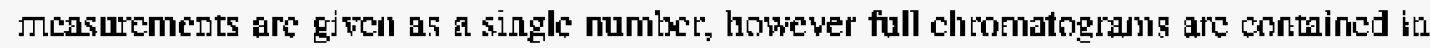
Appendix A.

Test analyses reveals wirtually one hundred peroest of the diesel range organics $\left(\mathrm{C}_{11}-\mathrm{C}_{24}\right)$ urere degraded in the dtums and aloost fifty percent were degraded in the water plase of the in-situ pil crearment rest. (See Table 1 and Appendix $\mathbf{B}$ ) The nearly lilty-percent degradalion of 
DRO is noteworthy ber-ause the levels were small to begin. Furthermare, the biamailatility of the contzouts nay hare been lintitod by age and moarhering.

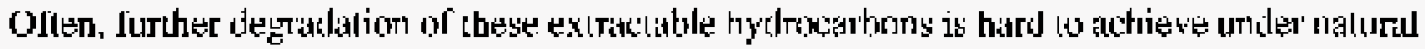
altenuation scenarios. This stall ito the degradation pathway is known as "bottle-necking." It is

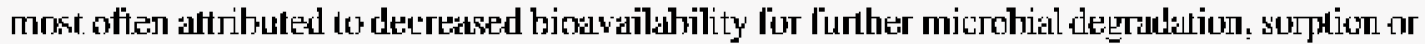
sulubilization of the hydrocarbon molech A key fundion of $\mathrm{CCOSAFE}^{\mathrm{TA}}$ techanology is its ability to bregktthsough the bottleneck atage and continue to make the arognie compounds hisavailable for treatment.

FPA Methon 8021B measures the BTEX chemicals (Benzese, Toluens: Ethylbenzene: and Xylenes\}. These are volatile moncaromatic hydrucarbons. They are considered one of the

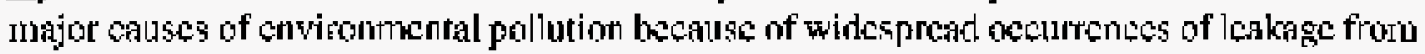
underground petroleum storage tanks and spills at petroleum production well, refineries,

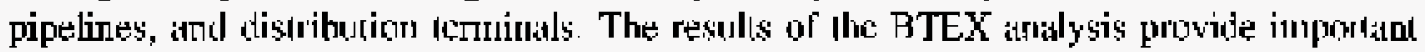
documeliation that ECOSAFE affectirely reduces the presence of these water solutide compounds. Baseline concontrations of these compounds were reduced to below the prastical quantitative limit of $0.5 \mu \mathrm{g} / \mathrm{L}$ afte+ treatment.. (Sice TabJe 1 and Appendix B) It should be noted that this test did not yuantify what percent of the BTEX compounds volarilized and what percent were degritide by irearment.

\section{Siummary}

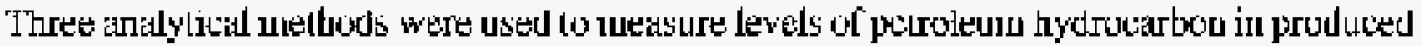
water from the in-situ pit treatment and a separate drum test in which fuld was treated with

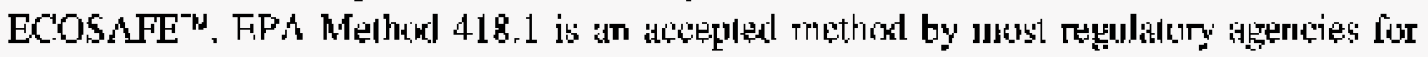
measuring hydrocathon contcht in soils and water. This methot is widely ohserved as a sereening tool saber bin a tuantitative representation ol 'specitic bydrocurbun content. Thus. variations in analysis results cam be cxpocted. In this test., analysis results showed an $83 \%$

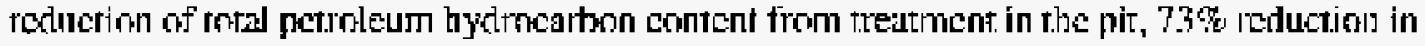
Drun No, I and a gyo reduction in Drus. No. 2.

Specific analysis for diese] range organics $\left(C_{10}-C_{23}\right)$ illustrates significatt reduction of these

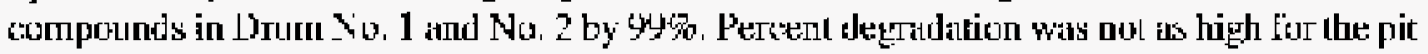
sanple, howeter baseline levels were low bo begin and the bivavalabilily of these compounds mily have heen allecled by alge ald wethening.

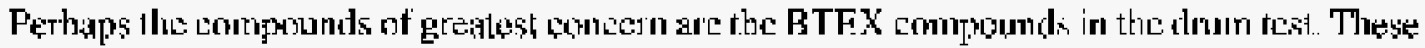
compounds are highly soluble in water and difficult to treat thereby posing a major risk to

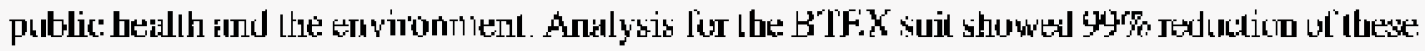

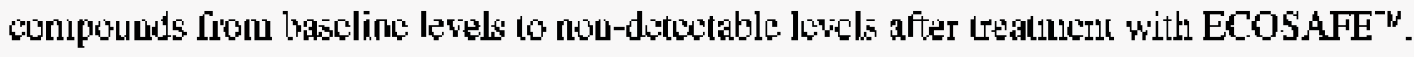

Lahoratny analyses results ane suminarized helow in Table I. Full lahoratory reports are contained in Appendix A. 


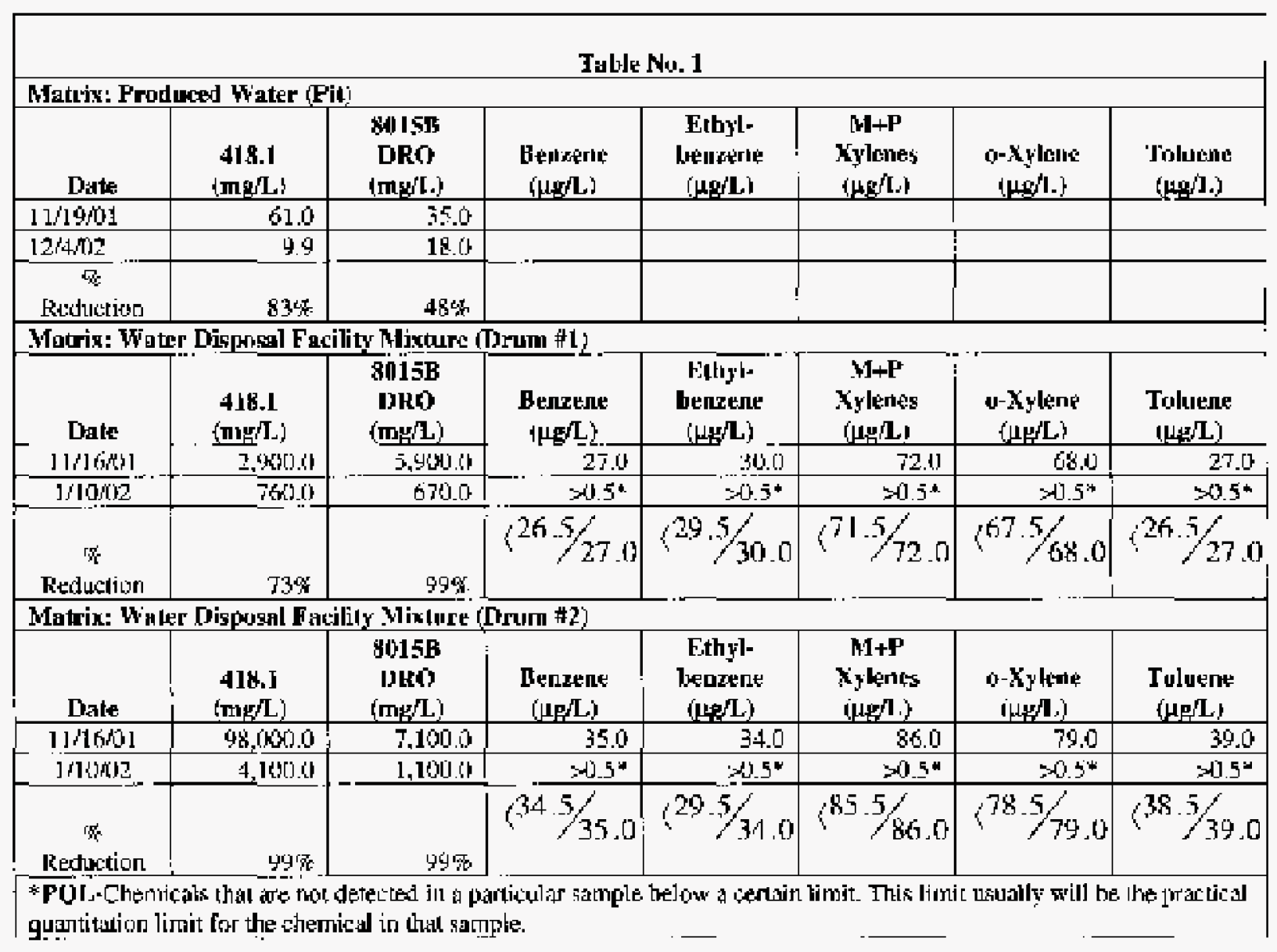




\section{Referentses}

Using TPH ln Risk-Based Carretive Action, by Joln B Gustafson, Shall, Development

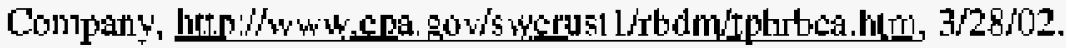

HTEX Metabolizro Metapathway Malp,

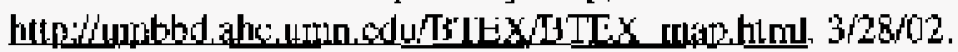

Chapelle, Fraucis H., Robertson, John F, Landmeyer, lannex F. Bradley, Paul M,

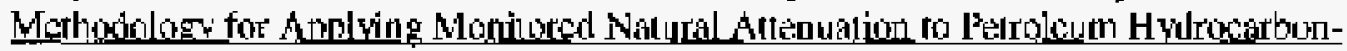
Contaninated Ground-Watol Sytems with Fxamples from South Canolina, LI.S.

Geolopgat Suryy Water-Resoures lnvestgalions Report 00-4161,

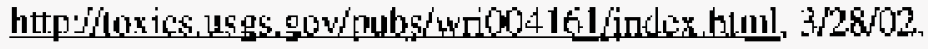

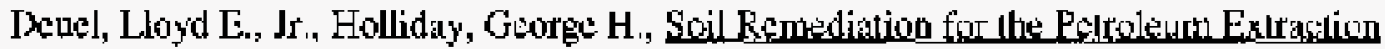
mdustry, PennWoll Publishing Campany, 1904.

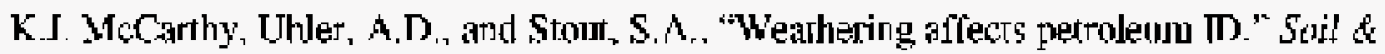
Grondwer Cleww, Angust/September (1908).

Toal Petroleum Hydtocarhon Working Groups Series, Woluwe 5 Human Health Riskbesed Fviluation of Petoleum Release Sites: Implementing the Working Group Approach. Pross (1999).

Sublette, Kery l... Ph. D.. The Uniwersity of Tulsa, Continuing Enginesing and Science

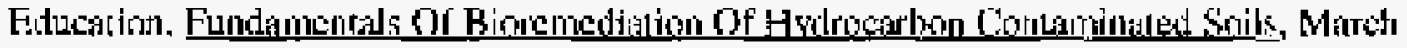
506. 2001. Tulsa, Oklahoma. 
APPENDIX A 


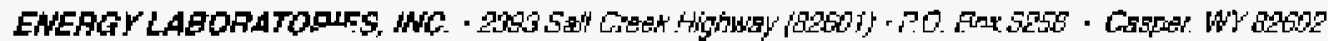

\section{I.ARORATURY ANALYTICAL REPORT}

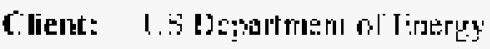

l'raject: R/MOl':

Lab ID: 50201020 [1\%]

Clinal Sample ID: FMOTE: : :
Report Ijate: 41:21:02

Collection Late: t1:1002 14:20

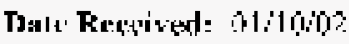

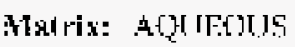

Meili:

Auslyos

vocs

Berrzeri:

Filhilbarze ie

$m+\mathrm{p}$-xylenes

oxplen=

- חuluente

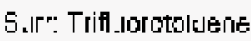

Metru interterence coused Increses a RL

ORAANIC GHARACTERISTICS

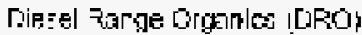

gtel Fetroleur Hidragarbans
Hesult [inith Qug]

N

$\mathrm{N}$ CF

NL

$\mathrm{ND}$

NDF

92.7

IJIL

uş'L

บg'L

U'.'L

บฏ.'L

"THER:

$57 \mathrm{C}$

nụit

7ET

mg:L
100

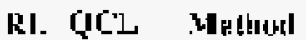

250

2.50

550

5.50

250

90-17.

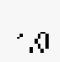

E4t8: hralysis Dute : Bq'

01112:02 02:33 i ilr 0 1:12:02 02:39 i ilr

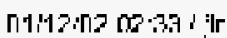

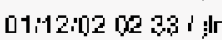

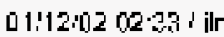

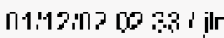

\begin{tabular}{|c|c|}
\hline 5以HB̄ำ1日 & $01112: 02$ 02:35 i ilr \\
\hline SพNAธ̄23日 & 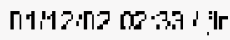 \\
\hline 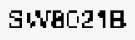 & 01,12102 oc 38 i \\
\hline GHEDE? & $01,120202.05$ ilr \\
\hline Wh-9? & ri i i \\
\hline
\end{tabular}

BWRE1FH a 5

ก1:18m? 16:27:

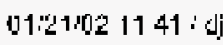

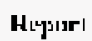

IIdinilians:

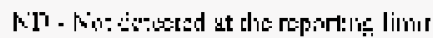

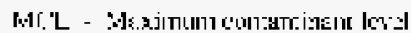

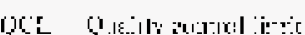

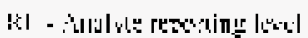




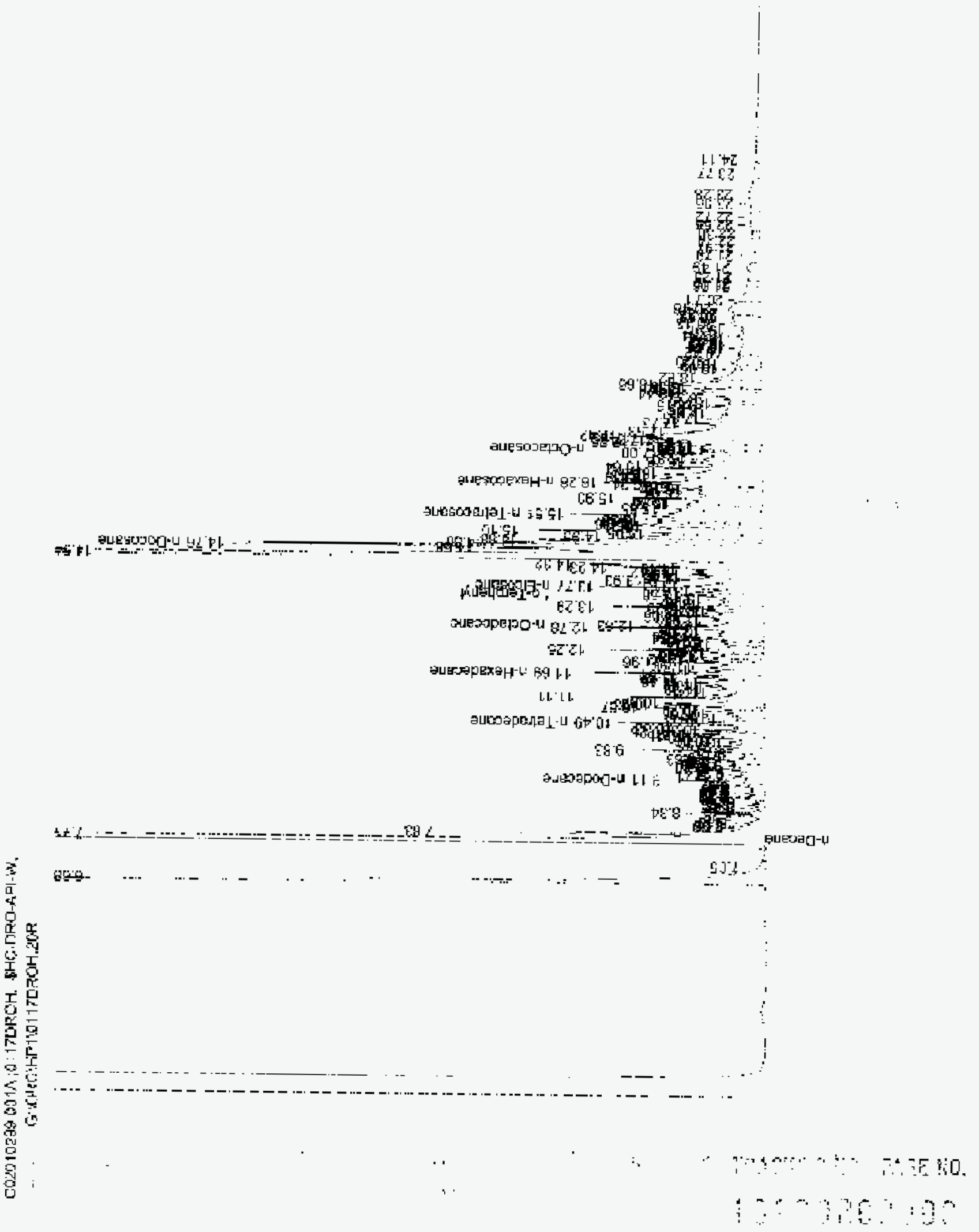


Clietila

Projest: R kidotr:

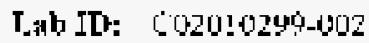

Clinn Sample W: TRMOTC Lum it2
Repor Braten 01:21:02

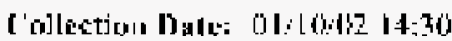

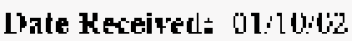

Hatcis: AQLEOL:

Mit' $\mathbf{L}^{\prime}$

Allaly'ses

\section{MOCS}

30 -20no

Etwoonzeria

in ${ }^{2}$.

$r_{i}$ Kolgone

TEi llene

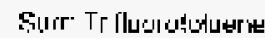

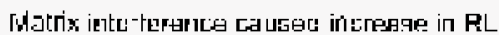

\section{ORGANIC CHAFACTERISTICS}

Jasel l tenge orgenics (CFi)

Total Fritrolaturn tydrocarane
Result Qnjt:

M.

Tr

Inth

ICT'..

hD L.G IL

ND U

go.3 CHEC

1100 mbis

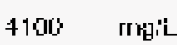

25

2.)

25:

P.

나이

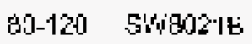

100

1:]

\section{Sth}

SWMUt:

$54+30215$

F⿻川

5wingog:

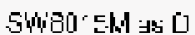

$E \neq 18.1$
Awglpan Inale i $\mathrm{By}$

$011^{2} 20293.5 \mathrm{k} ; \mathrm{j}$

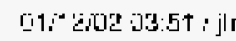

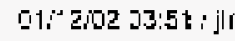

ㅁ. 1 -

L11 1020351 i

01.' 2010151 ! jli

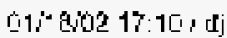

r.1:2102 11:41; t:
Hexpert

In' Tuilimas:

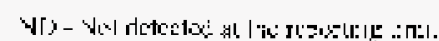

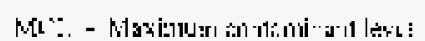

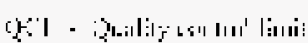

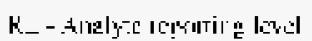




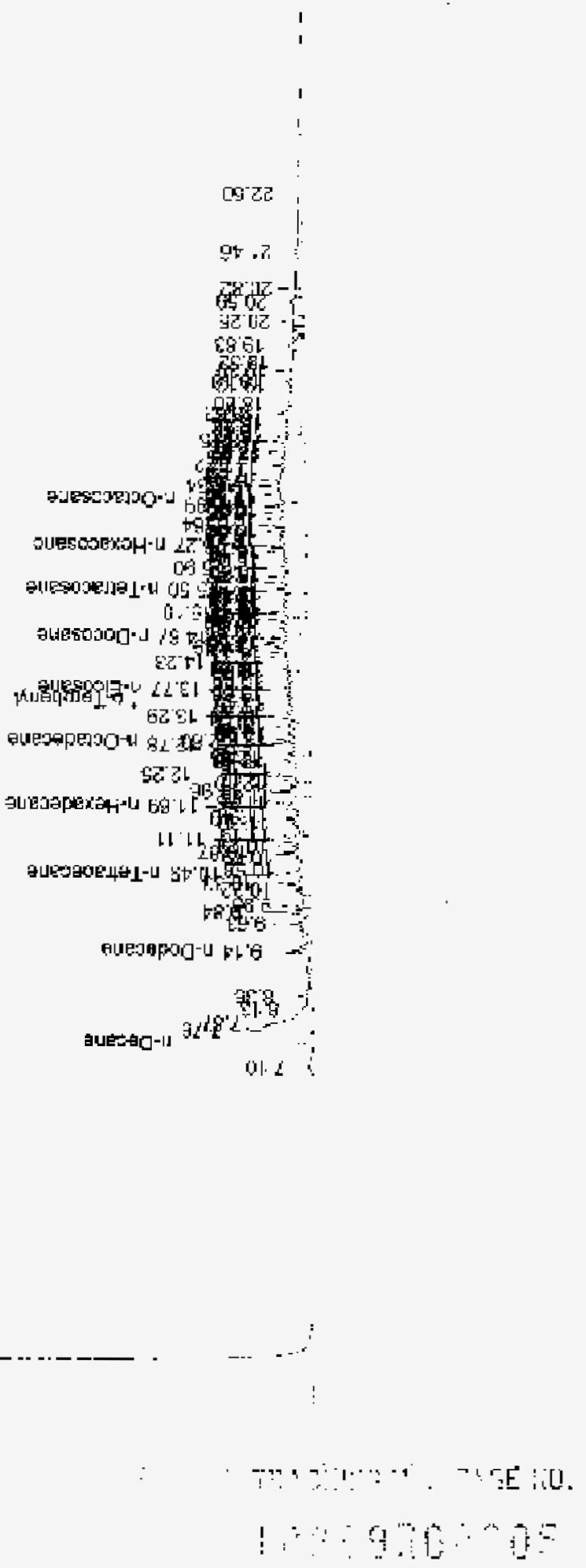




\section{LABORATARY ARAI YTICAI. RFFORT}

Clien1: L's Departrkent of Ejergy

Projcet: RuOTC: Tes Pil tí1

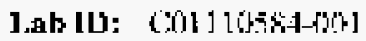

Clent Sample ID: BRTOTC: Drum ti!
Hepart Dato: 1206: I

Collection Date: 1 I:16\%? 14:47

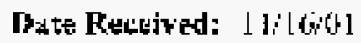

Matrix: Agl:orts

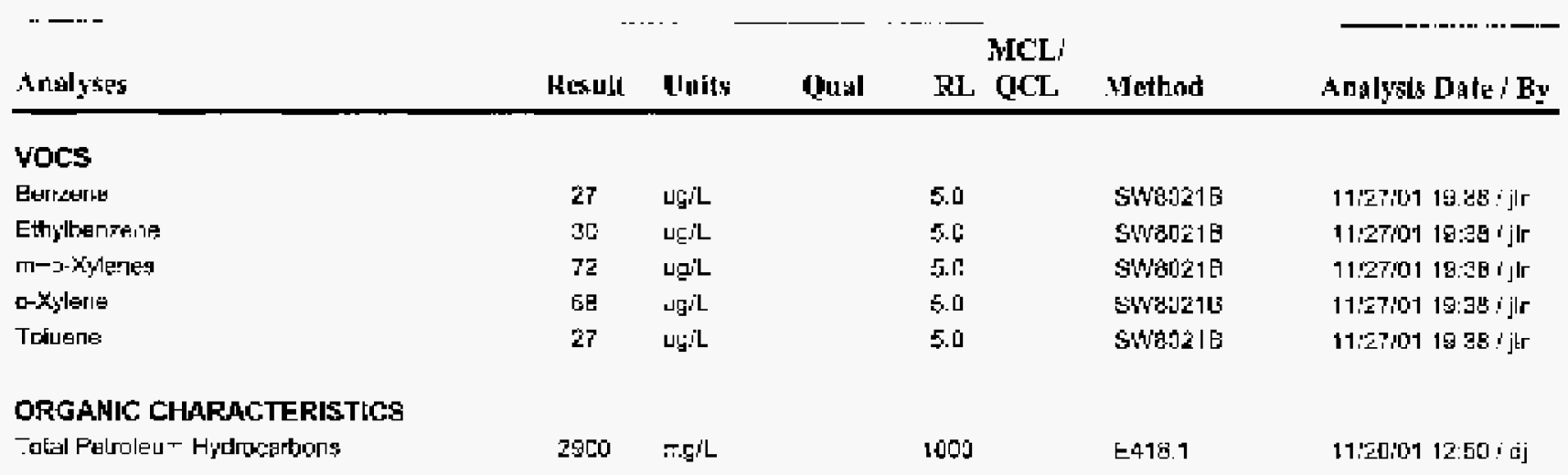

Exporr

Deē̃ntelulas:

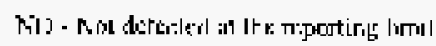

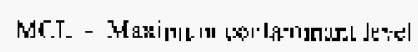

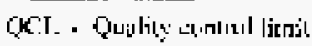

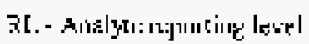




\section{LA HOHATCHY ANATYTTE AT. RFFORT}

Cyleut: CS Deptrtment of Erecrey

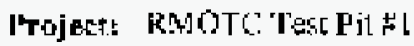

Lah ID: Cö110584-0n?

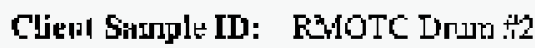

Report Dute: 12.01:191

Colleclion Date: 11:16:0115:00

Date Rectirgd: I Jilsid

Matrix: AQLEDIS

\begin{tabular}{|c|c|c|c|c|c|c|}
\hline Analyos & Result & Liniite & Uual & FL IMLII & Mellıni & 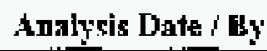 \\
\hline \multicolumn{7}{|l|}{ MOC5 } \\
\hline Eienzẹnét & 35 & 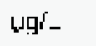 & & 25 & 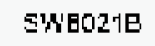 & 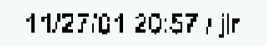 \\
\hline Lthytbenzena & 34 & ISíl- & & 25 & 5450218 & 1127ib 20:5i i Ji \\
\hline$\because+p-x y$ Honss & 86 & 나민 & & 25 & 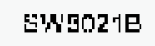 & 11/27iñ : 20:57 ; j|r \\
\hline oryilene & 79 & L怗 & & $2 \overline{8}$ & 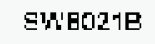 & 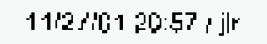 \\
\hline Tolü 7e & 79 & 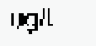 & & 25 & 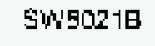 & 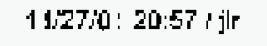 \\
\hline \multicolumn{7}{|c|}{ DRGANIE CHARACTERISTICS } \\
\hline Tutal Pelroleuri Hydrucartums & 98000 & mgl't & & 1.0 & $E 4+8.7$ & 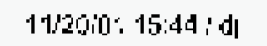 \\
\hline
\end{tabular}




\section{LABORATORY ANALYTICAL IRLTORT}

Client: ESS Dopartment. al Tintroy

Projet: RMOTC Test I'jt ț

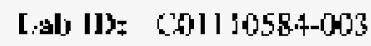

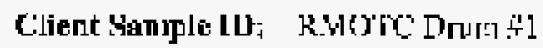

Repurt Date: 12:0101

C'alketton Dalk: 1 1:17:0] wh:15

Jate Recejwed: 11:16:01

Hat.jix: AOLEOUS
Analy ser

ORGANIG CHARACTERISTICS

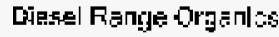

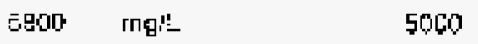

MCL

Result Linits

Qual

Hï QCL MLthod

Analysis Date / By

5N.

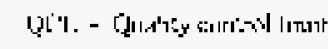

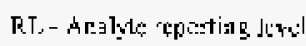




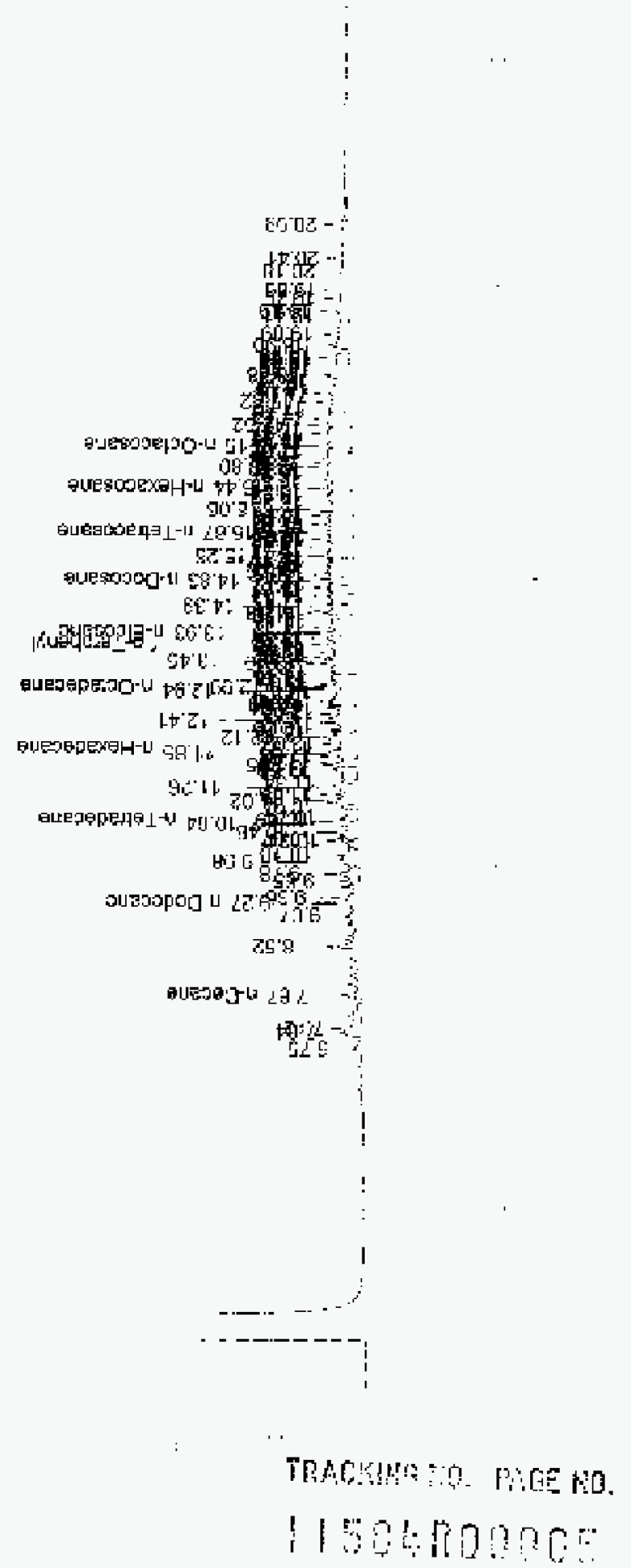




\section{LABORAIUKY AYALYTLCAL RKPORT}

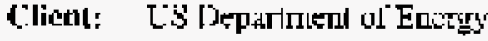

I'roject: ExMO'TC. Test Pil 1

Lib 1D: Co1105:-014

Cllent Sumple IT): RMOTC. Dnurn it?
Report lote: 12010101

Cullection Date: 11/17:01 0r:13

Dale Rexejvedf 11:16iol

Mlatrix: AQUTCLS

\begin{tabular}{|c|c|c|c|c|c|c|}
\hline Allalpscs & Result & Iinfrs & Qual & FL QCI. & Methud & Anglysis Date: $\mathrm{B}_{3}$ \\
\hline Dlesel Farige Crofrios & $7 \times 0$ & $\because g \mathrm{~L}$ & & 600 & Swan154: as $\mathrm{C}$ & 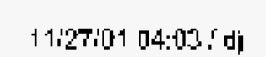 \\
\hline
\end{tabular}

H치바 rt

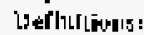

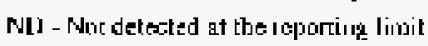

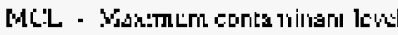

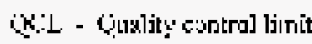

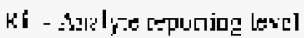




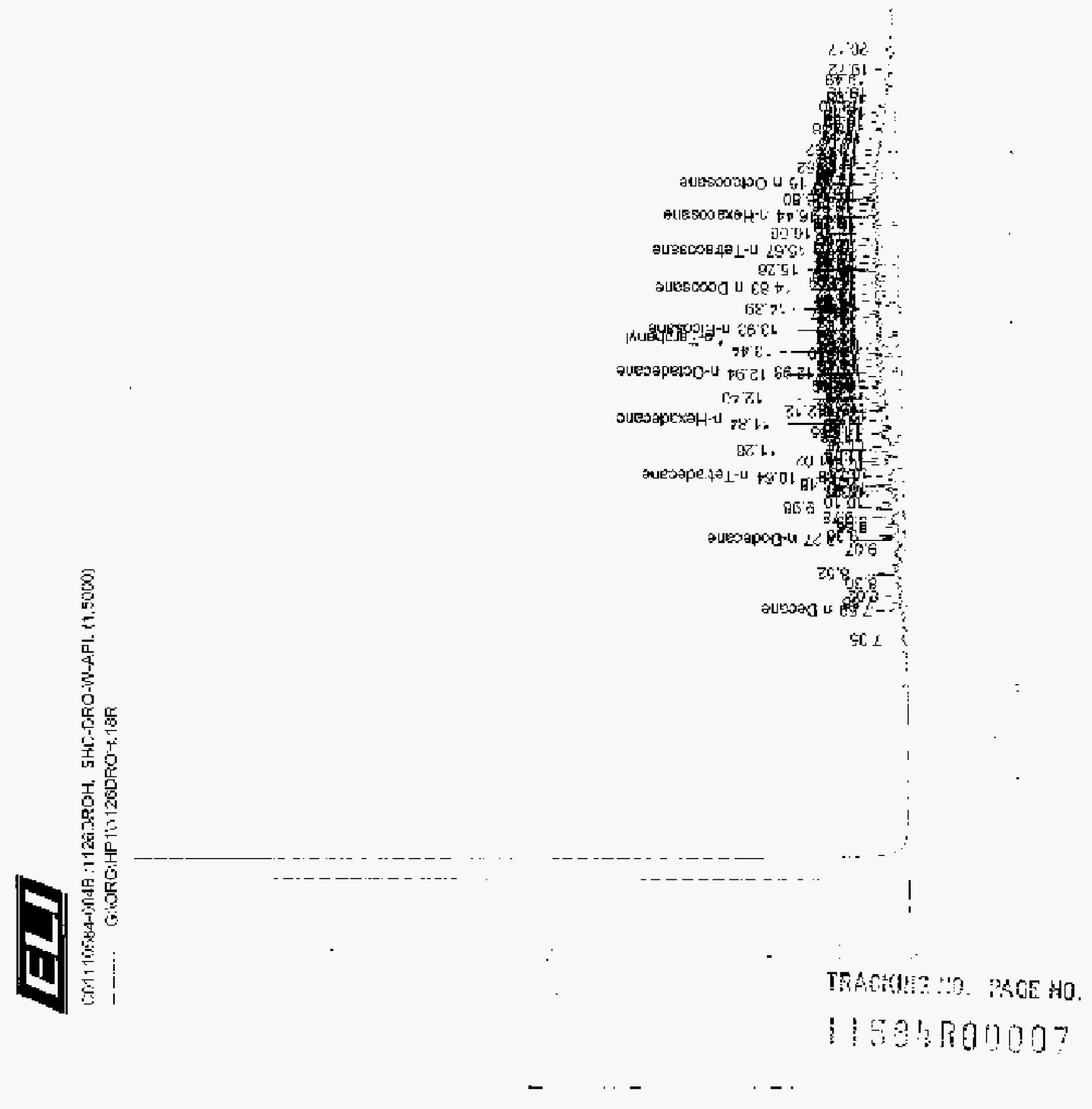




\section{QA'QC Summary Report}

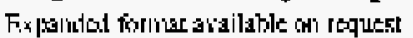

Client: TS Departunat of Energy

Repurl Dale: 12:0301

Irojec1: RlwOTC Teы Pit

Hurk Oruler: Col110584

\begin{tabular}{|c|c|c|c|c|c|c|c|c|c|}
\hline Ansylyt & Rqgiv|lk & リח跑 & PQL & YPEC & Low LimTlt & Hilgh Llmit: & FPPQ & RPPLImIIt & QUEI \\
\hline Method: E4tid & & & & & & & \multicolumn{3}{|c|}{ Uatch: व11120A-НL-TPHНҢ-W } \\
\hline Samplé ID: MELK1_011120A & MPLK & & & & & & \multicolumn{3}{|c|}{1100 191 12:5 } \\
\hline Tots Petroleuri Hydrocatbons & 0.3418 & mitl & 1.0 & & & & & & 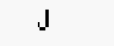 \\
\hline Săhale ID: MULK1_011120AMs & M5 & & & & & & \multirow{2}{*}{\multicolumn{3}{|c|}{11271255}} \\
\hline Tote Petroleanin Hydrowerbons & 5.154 & mall & -1.0 & 163 & 70 & 130 & & & \\
\hline Sample ID: HEEK1_011120AMSD & $M 5 \Gamma$ & & & & & & \multirow{2}{*}{\multicolumn{3}{|c|}{$\begin{array}{l}t 1 / 2: 10 \cdot 112: 50 \\
20\end{array}$}} \\
\hline | ot Petroloum Hydrocearons & 5.122 & $\mathrm{mg}$ & 1.0 & 102 & 70 & 130 & & & \\
\hline Methed: SWadr5M at D & & & & & & & \multicolumn{3}{|c|}{ Evich: 544} \\
\hline Sample ID: WE-5-44 & MELK & & & & & & \multirow{2}{*}{\multicolumn{3}{|c|}{ 1126:0118-47 }} \\
\hline Diegel Ranga Drpanice. & MD & mg:L & 1.5 & & & & & & \\
\hline Выл: пి-Teraheny| & & & 0.10 & म2.5 & 75 & $12 \overline{5}$ & & & \\
\hline 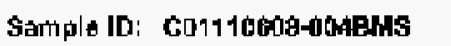 & $M 5$ & & & & & & \multicolumn{3}{|c|}{112 silt $72: 22$} \\
\hline L cosel Fange organics & 20 & Trझ̆l' & 10 & 100 & eq & 140 & & & \\
\hline 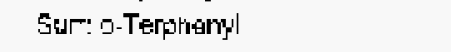 & & & 1.6 & 252 & 75 & 125 & \multirow{2}{*}{\multicolumn{3}{|c|}{$11 / 25,0123: 04$}} \\
\hline Sample ID: Co111060a-004BhsD & $M S D$ & & & & & & & & \\
\hline Diesal Fürige Drganics. & 20 & met'L & 11 & 100 & 60 & $14 \pi$ & \multicolumn{3}{|c|}{20} \\
\hline Surr: o-Terphengi| & & & 10 & 252 & 75 & 125 & 0 & 10 & Js \\
\hline
\end{tabular}

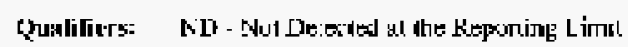

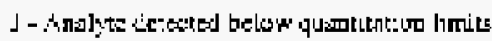

E - Moty
S-Spike Reiovery ourbide acecpted tecowery lir:ics

R. - R.PD outide gecoprod tesencry limica
Prise 1 af?

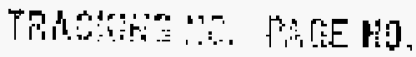




\section{QAiQC Summary Report}

Lxplanded format araljabie on reques:

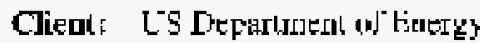

Report Dater 120301

Prujet: RWOTC Ty Pil मेt

Wurk Order: coll10584

\begin{tabular}{|c|c|c|c|c|c|c|c|c|c|}
\hline Analyte & Fiegult & Uח & PQL & \&PE्E & Low LImit & Hlgh Limit & $\mathrm{YHFPQ}$ & RPDLimit & | \\
\hline hethod: swente & & & & & & & & \multirow{2}{*}{\multicolumn{2}{|c|}{ 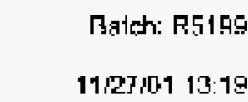 }} \\
\hline Sample |D: WBLK_112THPr05 & B 아년 K & & & & & & & & \\
\hline Bonzene & $\mathrm{ND}$ & uوالوالو & 0.50 & & & & & & \\
\hline 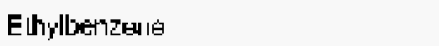 & ND & Uğ' & 0.50 & & & & & & \\
\hline$m+p-x y \mid=7=s$ & MLV & 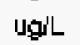 & 0.50 & & & & & & \\
\hline Mol'yl iort-butyl ather (PATEE) & NO & لإل & 2.0 & & & & & & \\
\hline 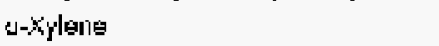 & $\mathrm{ND}$ & Lgوا & 0.50 & & & & & & \\
\hline Taluené & NLt & Lgو & D.F5 & & & & & & \\
\hline Silur. Triflumintot. Jene & & & [1.5... & $\infty .4$ & En & 120 & & & \\
\hline Samble |D: Co1110664003Ans & $\mathbf{M E}$ & & & & & & & \multicolumn{2}{|c|}{$11270118: 20$} \\
\hline Bunzzarit & He & ugit & 25 & B..6 & 70 & 130 & & & \\
\hline Fthylparnene & $d T T$ & $\operatorname{lng}$ & 25 & 94.5 & 70 & 130 & & & \\
\hline m י-Xylenes & 1010 & Ugil & 25 & $94 \ldots$ & di & 15 & & & \\
\hline 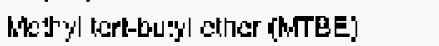 & 739 & ugl & 100 & 2.75 & 70 & 190 & & & 5 \\
\hline 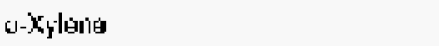 & 4ลA & Ugy'L & 25 & ㅁ. 3 & 70 & 130 & & & \\
\hline T해 .JE ne & 401 & Uوإl & 25 & 9.8 & 70 & 130 & & & \\
\hline Surr: Trifluorotedsene & & & 25 & 91.6 & 70 & 130 & & & \\
\hline Sample I0: CJ1110664-103AMSD & MSD & & & & & & & \multicolumn{2}{|c|}{$112+0116: 54$} \\
\hline Benz므e & 4.57 & ugg:L & $2 \square$ & Bj_L & 70 & 130 & 0,229 & 20 & \\
\hline Ethyltenzen: & 475 & $u g^{\prime}$ & 25 & 94.1 & 70 & 130 & 0.420 & 20 & \\
\hline m+n-צyleneg & $1 \sqrt{11}$ & ugit & 25 & 94.4 & 70 & 130 & $0 . \operatorname{lgg}$ & 20 & \\
\hline lke:hyl tert-b. a & 734 & ugl & 100 & 2.55 & 70 & 150 & 0.545 & 20 & 5 \\
\hline n-Xylene & $4 E \bar{r}$ & "yاl & 25 & 92.1 & 70 & 130 & 0.205 & 20 & \\
\hline Toluene & 460 & ugL & 25 & Wo.t. & 10 & 130 & 0.217 & 20 & \\
\hline Eurr: Trifuongtol:Jeng & & & 25 & $\infty 0_{-4}$ & 70 & 190 & $\sqrt{7}$ & 20 & \\
\hline
\end{tabular}

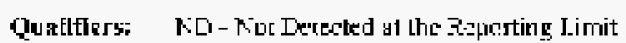

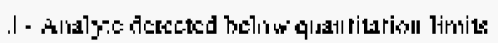

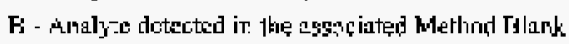

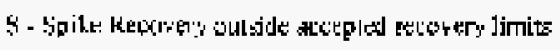

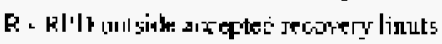

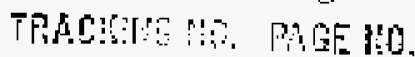




\section{LATORATCRY AYAT.YTICAL KLPOHT}

Clienl: US Ilepartment of Encrers

Project: Not Indicated.

Lub IIt: Co1120004-0ith

Clienl Simple ID: RMOTC Iir ti.

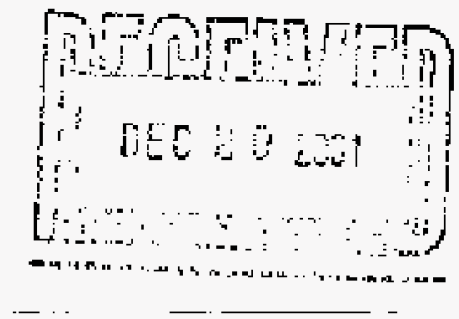

MCL

Adajyges

Resutt Unils

Qual

RL QCL

Analysis Dare i By

ORGANIC CHARACTERISTICS.

마려이 Fiange 0rgan|cs

18 mgit

10

9.9 mgil

1.0

$120610 ; 203 \mathrm{~s}$

Fotgi Petreleurn Hirtrocatons
Nethind

SWHo15M as [

Fepart Date: 12:13:01

Collection Date: 12/0d:11 11:30

Dote Reccired: [26401

Mlatriz: MOUEOU:

$E \div 16.1$ 1240i5i $15: 41$ id

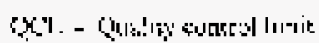

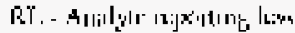




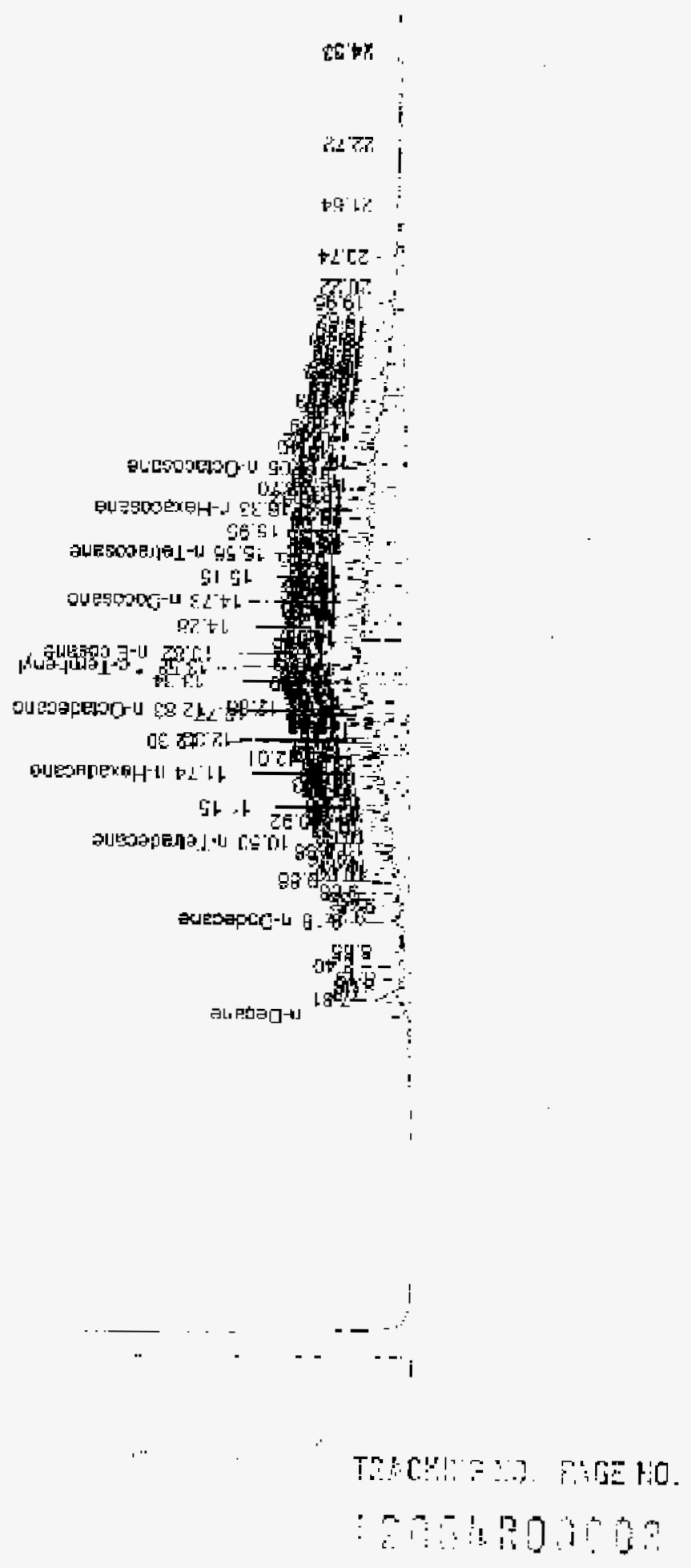




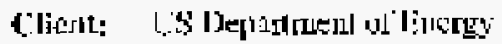

l'roject: vart Itadearet

Tath II): $\quad 01110592001$

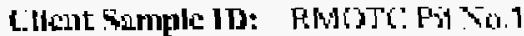

Report Date: ] 1:28: J1

C:allection bate: 11:13:01 19:I:

Date Receirall: I Ji19:01

MItrix: hQUTOT

MiC.L.'

Allalfsics

\section{ORGANIG CHARACTERISTCS}

Diege Finga organlos

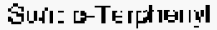

DRGANIC CHARACTERI\$TICS

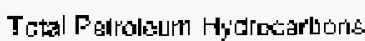

$35 \quad$ mgiL

$250 \quad$ RREC

6

mgi't
101

$75-125$

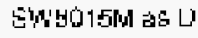
SNEDTSW aE

เ416.1
Mndysis Dale / Bu.

$1125: 512344 ;$ : d

$1125 i c 12347$ id

112501 12:21， d.
Repuirl Intinili in na

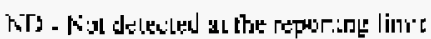

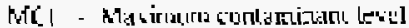

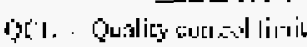

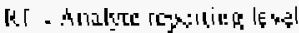

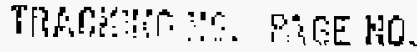




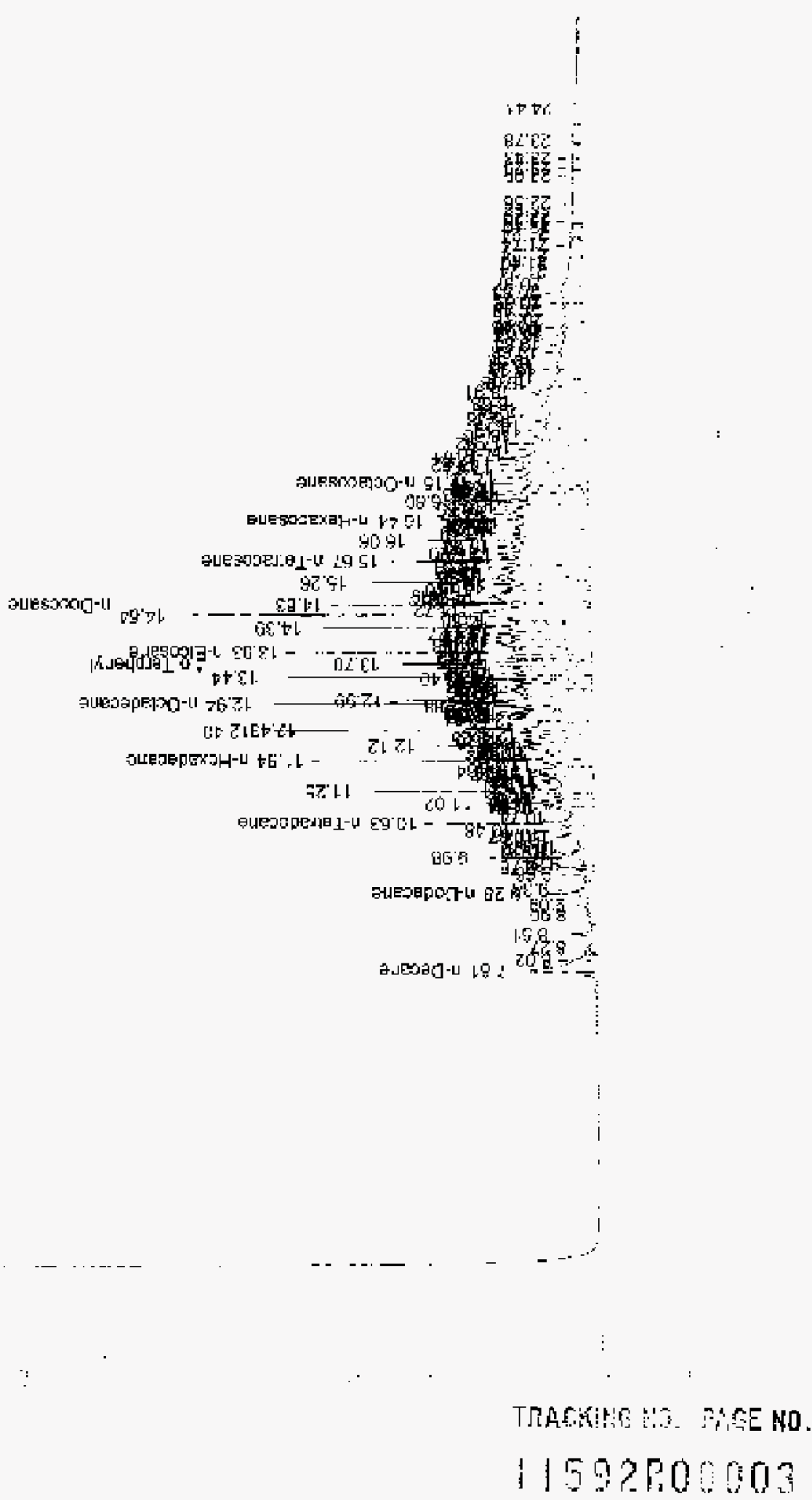


APPENDIX B 


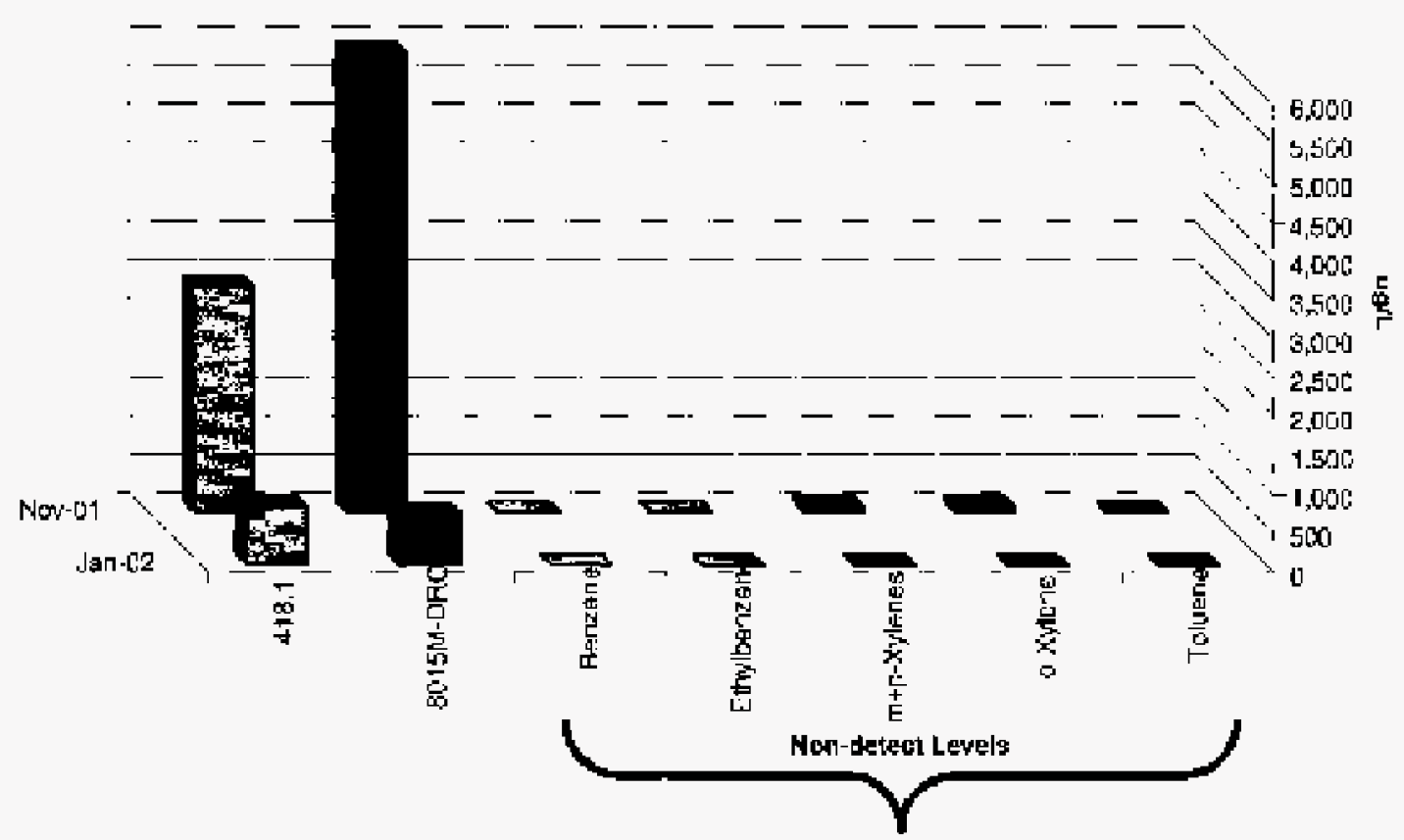

Fignre 1 Lah Anulysis Kosults for Drum No. 1 


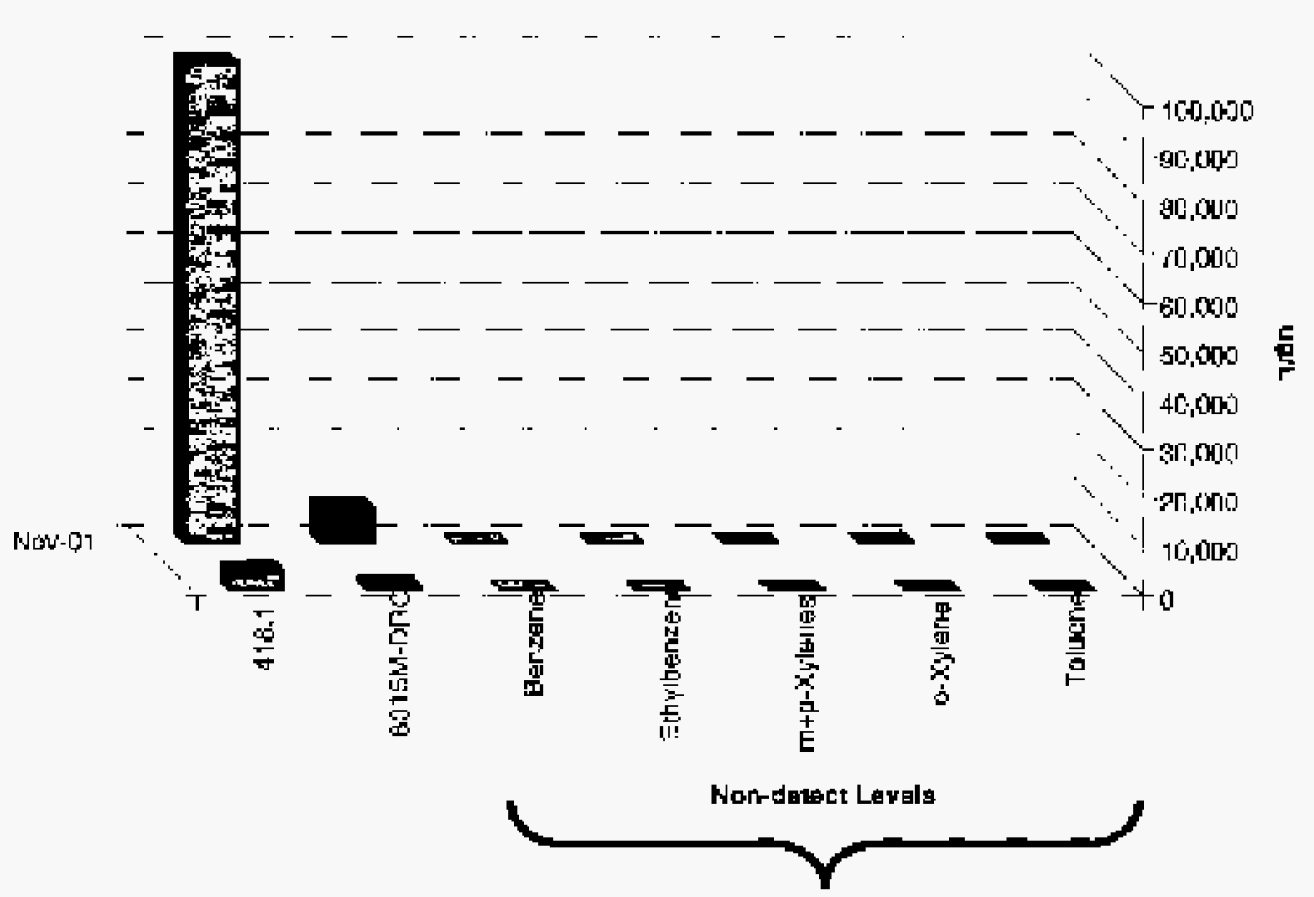

Figure 2 Inb Anglysis Results for Drum $\mathrm{No}_{+} 2$ 


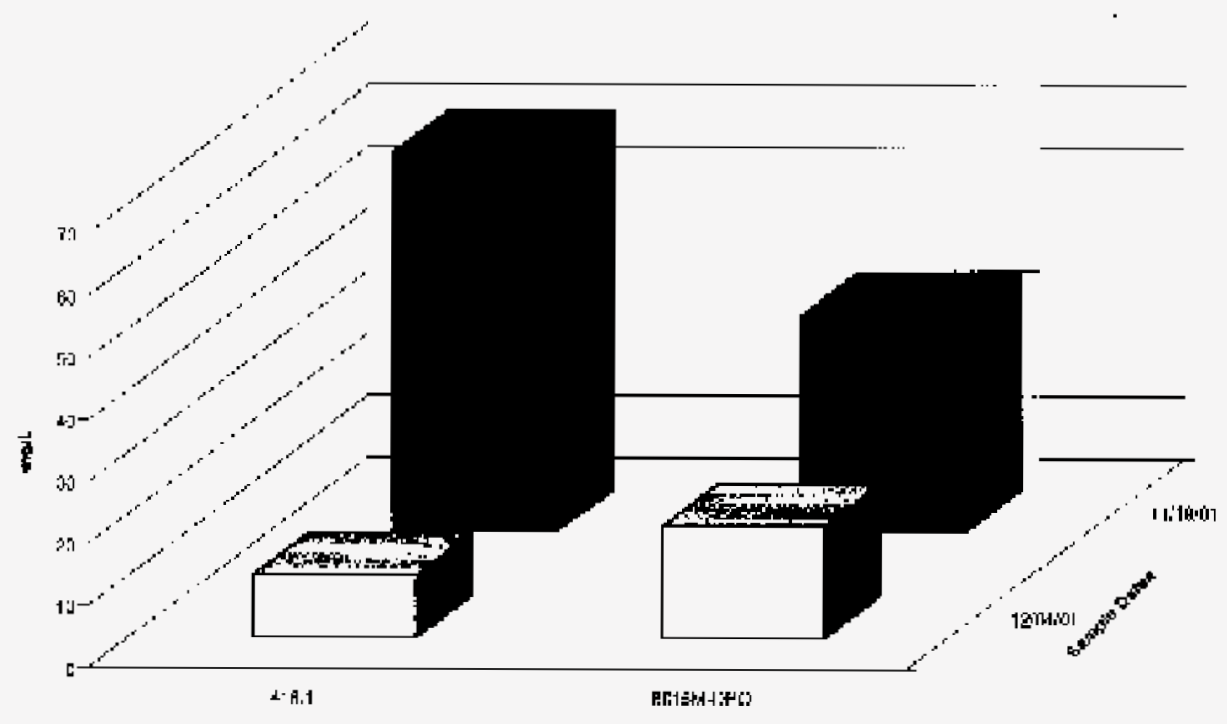

Figure 3 Analysis kesults from kMOYIC Pit - Prnducerl Water Matrix 


\section{APPENDIX C}




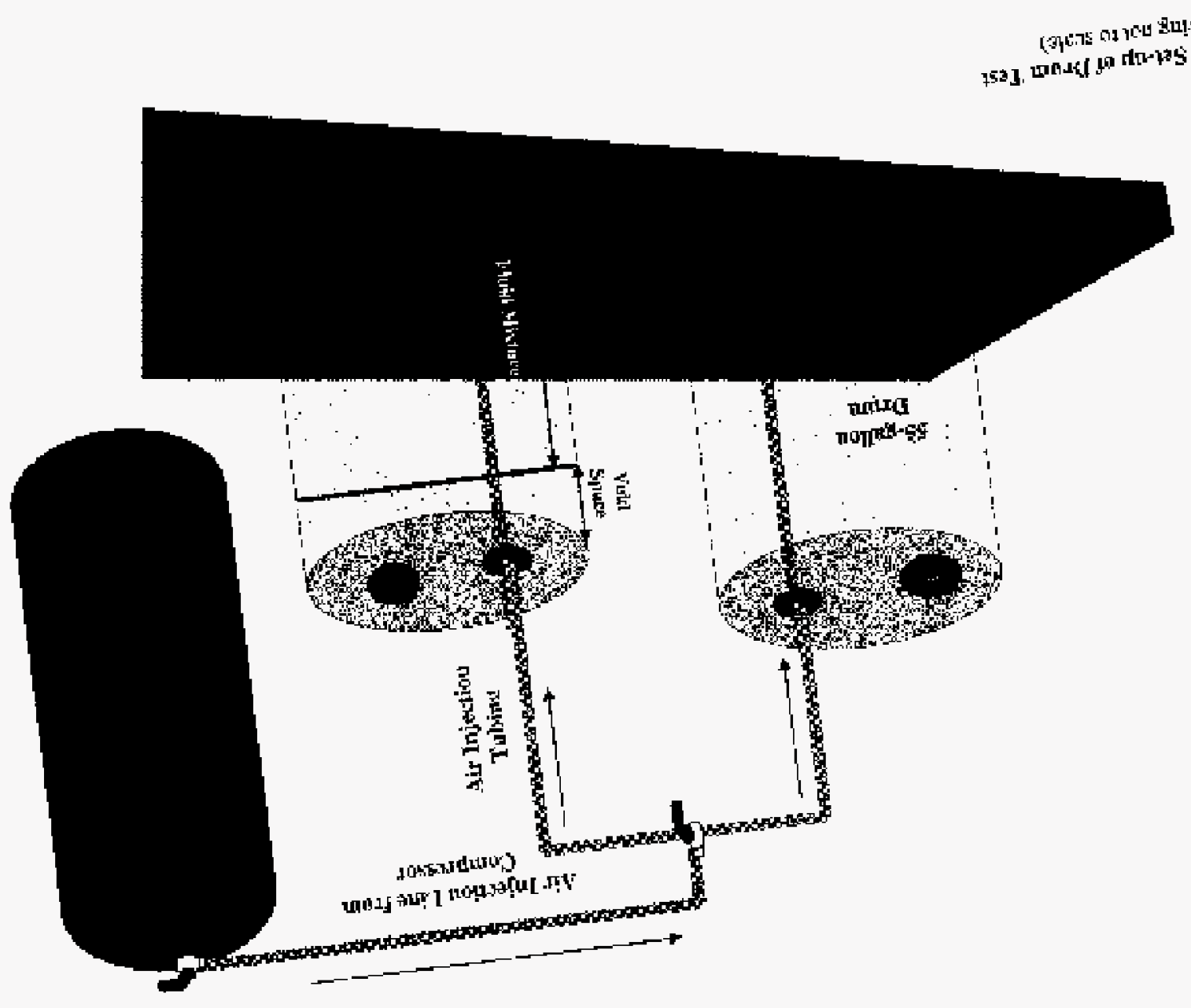

